\title{
China's Power Status Change

\author{
East Asian Challenges for \\ Xi Jinping's Foreign Policy
} \\ Malcolm Cook
}

\begin{abstract}
Rapid changes in power relativities inevitably aggravate security fears among smaller, weaker states and those in relative decline. The closer these states are to the major power and the deeper their historical relationships with it, the more this is true. It is preponderant on rising or remerging major powers to assuage these worries in word and action. If not, the rising or reemerging power will face resistance. Under Xi Jinping, Chinese foreign policy has embraced China's status as the leading power in East Asia and one of two major powers globally. Acceptance and support for China's new major power status and corresponding regional initiatives like the Asian Infrastructure Investment Bank and a "new Asian security order" face three particular challenges in East Asia. The first challenge is increasingly public concerns about possible future Chinese hegemony with the East and South China Sea disputes, in particular aggravating these worries among the non-Chinese disputants. The second challenge is the disruption of the liberal virtuous cycle between growing economic interdependence and more aligned strategic interests and greater strategic trust. The third is the strengthening of alliance and
\end{abstract}

Malcom Cook is Senior Fellow at the Institute of Southeast Asian Studies, Singapore.

The author would like to thank Vandana Nair, a research officer at ISEAS, for her research support and to his other Institute colleagues for their useful feedback on an earlier oral draft of this paper, as well as the anonymous reviewers for their precise and insightful comments.

(c) 2015 World Century Publishing Corporation and Shanghai Institutes for International Studies China Quarterly of International Strategic Studies, Vol. 1, No. 1, 105-131

DOI: $10.1142 / S 2377740015500062$ 
security partnerships between the United States and a growing number of East Asian states from Vietnam and Singapore to the Philippines and Japan. Chinese foreign policy under and after $\mathrm{Xi}$ Jinping will have to respond to these concerns and reassure its East Asian neighbours in order to succeed.

Keywords: China; East Asia; foreign policy; hegemony; alliances.

It is clear that Chinese foreign policy under $\mathrm{X}_{\mathrm{i}}$ Jinping and after will be judged by other states as that of one of the only two major global powers and East Asia's leading one. Increasingly, East Asian analysts and officials view that China has risen and reemerged, it is no longer rising or reemerging. This status change in perception of and reaction to China is most noticeable and most challenging in East Asia. China's growing importance internationally means that China's actions in East Asia and the reactions of East Asian states to these actions are gaining more global attention and helping to shape global views of China's foreign and security policy actions and intentions.

The responses of East Asian states to the return of China's leading position and more assertive defense of its maritime sovereign claims are challenging three core pillars of

Increasingly, East Asian analysts and officials view that China has risen and reemerged, it is no longer rising or reemerging. China's foreign policy rhetoric. The three pillars under challenge are China's anti-hegemonic claims, the liberal belief that closer bilateral and regional economic integration should lead to better strategic relations, and Chinese hopes for a new Asian order with a reduced role for the U.S. and its alliance and security partner relations. Adapting Chinese foreign policy rhetoric and actions to address mounting East Asian concerns about China that lie behind these three challenges will not be easy, but it will be crucial for a positive reception of China's renewed leading position in East Asia and rising position globally. As it is impossible to gain a full and objective understanding of China's engagement with East Asia, this article will focus on these three challenges facing foreign and security policymakers in Beijing now and into the future, as well as the often critical assumptions and perceptions of Chinese actions that inform them. 


\section{Status Change}

The combination of three characteristics of China's reemergence over the last three decades has made it uniquely difficult for international relations scholars and practitioners to clearly identify China's present power status in the inter-state system and the assumed responsibilities and behavior that stem from that status. ${ }^{1}$ China's population is disproportionately large, with only India in the same size category among the roughly 200 states in the world. In 2006, China Daily noted that China's population of disabled people was as large as the total population of Germany, the European Union's most populous country. ${ }^{2}$ China's population is roughly four times larger than that of the United States, the third most populous country in the world.

Second, this disproportionately huge population size, when combined with China's disproportionately rapid, sustained, and ongoing economic growth rates now, means that only the size of the U.S. economy is comparable to that of China. In a decade, China's economy will likely have no peer on this foundational measure of national power in the inter-state system. The consequent expansion of Chinese declared defense spending, another foundational measure of national power in the inter-state system, means that Chinese defense spending now easily surpasses all other states except the United States. According to the military expenditure database by the Stockholm International Peace Research Institute, in 2013, estimated American defense spending in constant dollar terms was 3.4 times greater than that of China. This same database records Chinese spending as accounting for close to 60 percent of total defense spending in East Asia, roughly four times as large as Japan's and India's spending respectively. ${ }^{3}$

${ }^{1}$ To a lesser extent, the combination of these same three characteristics complicates clear identification of India's present position as well. See Baldev Raj Nayar and T.V. Paul, India in the World Order: Searching for Major-Power Status (Cambridge: Cambridge University Press, 2003). These authors use the term "status inconsistency" to describe the problem.

${ }^{2}$ Inge Abraham, "Ambitious Vision for Keeping in Touch," China Daily, December 28, 2006.

${ }^{3}$ Stockholm International Peace Research Institute http://www.sipri.org/research/ armaments/milex/milex_database Data in 2011 constant dollar terms. SIPRI figures are used as they are most widely cited. Military spending figures from the International Institute of Strategic Studies and from IHS Jane's list show Chinese spending is lower in comparison to Indian spending. 
The third characteristic is at the core of much of the status identification confusion and debate. Though now by some measures the largest national economy in the world, China is still a developing economy with a population in poverty matched in scale only by India. Using World Bank statistics, in 2011, the number of Chinese living on $\$ 2$ a day (in purchasing power parity terms) or less was greater than the total population of East Asia's next most populous country, Indonesia. ${ }^{4}$ In short, China is the first developing economy to have achieved major global power status.

\section{Different Characteristics' Combinations}

Informed by the uniquely impressive statistics associated with the second characteristic, the dominant international narrative on China has focused on the first two characteristics, population size and economic growth, and uses the third, China's developing economy status, as a reason to believe that China's sustained high rates of growth will continue long into the foreseeable future. China is already one of the two major global powers now, and it is likely to become the largest and most powerful in the future - and in a class of its very own. Scholars and commentators focused on this chosen combination of Chinese characteristics have opined that

- China will soon "rule the world";

- China is the standard bearer of a superior global development paradigm, the Beijing Consensus, to the Washington one;

- China is one of the two "Gs" that should work with the other, the United States, to lead the global response to global challenges; and

- China poses to East Asian states a present, stark strategic choice between continued alignment with the eroding power of the United States or acceptance of Chinese regional primacy. ${ }^{5}$

\footnotetext{
${ }^{4}$ There were approximately 250 million Chinese poor by this measure in 2011. Indonesia's 2011 population was approximately 244 million. Statistics can be found at http://data. worldbank.org/?display=graph

${ }^{5}$ Martin Jacques, When China Rules the World: The End of the Western World and the Birth of a New Global Order (New York: Penguin, 2009); Joshua Cooper Ramo, The Beijing Consensus (London: The Foreign Policy Centre, 2004); C. Fred Bergsten, "A Partnership of Equals; How Washington Should Respond to China's Economic Challenge," Foreign Affairs, Vol. 97, No. 4 (July/August 2000), pp. 57-69; Hugh White, The China Choice: Why America Should Share Power with China (Melbourne: Black Inc., 2013).
} 
The last two decades have shown that this particular view of China as a strong major power has not remained cloistered in academic circles but has influenced other states' policy toward and expectations placed on China. Some WTO members, sensitive to their domestic commercial constituencies, pushed hard for China to be recognized as a developed economy and not subject to the WTO's "special and differential treatment" principle for developing economy members. ${ }^{6}$ The WTO is a consensus organization where all existing members must approve the ascension of a new one. This and the fact that the United States led the campaign to exclude consideration of China as a developing economy, despite the fact that it was, strengthened this campaign and the tougher terms China faced to join the WTO.

Likewise, China's developing economy status and comparatively low per capita greenhouse gas emissions did not save Chinese negotiators, led by then Premier Wen Jiabao, from being singled out for criticism for the inconclusive talks by leading politicians from other negotiating states. ${ }^{7}$ Echoing a different, less favorable "special and differential treatment" principle for China, some developed economy participants in the United Nations Framework Convention on Climate Change negotiations have tied their willingness to offer further reductions in greenhouse gas emissions to China (and India) doing likewise. No other Kyoto Protocol Annex 2 country faces such pressure from other member countries, developed or developing. As with the WTO ascension and China's central role in the global trading system, the fact that China was already the largest single emitter in present terms of greenhouse gas emissions was the justification for calling China to a higher standard, that befitting a major global power, than other developing economies at Copenhagen.

Chinese government officials have preferred to focus on the third characteristic of China's reemergence and how this acts, or should act, as a limit on what can be expected of China internationally despite its huge population size and its rapid, sustained and ongoing economic growth.

${ }^{6}$ Michaela Eglin, "China's Entry into the WTO with a Little Help from the EU," International Affairs, Vol. 73, No. 3 (July 1997), pp. 489-494.

${ }^{7}$ Ed Miliband, "The Road from Copenhagen," The Guardian, December 20, 2009 and John Garnaut, “China Thinks Rudd's Rat Tale Too Curly,” The Age, June 9, 2009. 
In 2012, Le Yucheng, Assistant Minister of Foreign Affairs, in response to international criticism of China, summed up this alternative Chinese narrative,

\begin{abstract}
Recently, some people accuse China of being a 'selective stakeholder' who switches between the role of 'elephant' and 'ant' as it sees fit. They want China to be a 'full stakeholder.' Such expectations are understandable. But China is, after all, an emerging country, a growing country with unbalanced development. For all its remarkable progress and strengths in certain aspects thanks to over 30 years of reform and opening-up. China still has many weak links. It is not unwilling — but unable - to take on more international responsibilities and fully play the role of a major country. Just like in sports: Though it won the most gold medals at the 2008 Beijing Olympics and has a comfortable lead in diving and table tennis, it is almost impossible for China to win a gold medal in football. ${ }^{8}$
\end{abstract}

Other officials and scholars, less diplomatic than Le, contend that foreign pressure on China to take up the responsibilities of a major global power, despite its developing economy status, has a more nefarious origin than the difficulty of status identification. Huo Jianguo, President of the International Economic and Trade Research Institute, argues that Western states want to burden China with responsibilities to "serve the Western strategy of curbing China's development." ${ }^{9}$

The concept of "comprehensive national power" developed in China by a range of scholars and research institutes also contradicts the widespread view of China as the world's second most powerful country soon to eclipse even the United States. The Chinese Academy of Social Sciences' 2009 ranking of states on this multi-variable aggregate measure placed the United States as number one, in aggregate and for each variable, and China

${ }^{8}$ Le Yucheng, "Ten Observations on China's Relations with the World," China International Studies, No. 34 (May/June 2012).

${ }^{9}$ Cited in Li Shigong, "Why is China Supposed to be Responsible for the World? Western Countries Have a Biased View of China," Beijing Review, No. 35 (September 2, 2010). 
in a lowly seventh place. ${ }^{10}$ According to this measure, China's comparative comprehensive national power declined from 2003 to 2006 (from third to sixth place) and from 2006 to 2009 (from sixth to seventh place). Using a different calculation of the same concept, Yan Xuetong put China in third place behind the United States and the European Union in 2006. ${ }^{11}$

More contextually, other Chinese officials and scholars contend that China's lack of experience in multilateral fora and the fact that the existing ones were all formed before China's reemergence as a major global power constrain China's engagement with and effective use of these core institutions of major power interaction and influence. ${ }^{12}$ The reactions Chinese negotiators encountered during the Copenhagen climate change summit from both developing and developed state negotiators add empirical credibility to this claim of lack of experience. China's disproportionately small share of World Bank and International Monetary Fund voting rights and the difficulties faced in adjusting these peak economic institutions to the post-1950s' inter-state system is a powerful indicator of the limits on Chinese influence and reciprocal responsibility in many of the main global multilateral bodies. ${ }^{13}$ International Relations theory has long expected rising or reemerging powers to seek to change the rules of existing multilateral fora or to establish alternative ones, for who sets the rules that guide these fora is seen as a key source of structural power. ${ }^{14}$

Moving further from the material to the abstract, Renmin University's Shi Yinhong presents another, culturalist reason why it is not correct to

${ }^{10}$ Cited in John Lee, “An Exceptional Obsession,” The American Interest, Vol. 5, No. 5 (May 2010).

${ }^{11}$ Yan Xuetong, "The Rise of China and Its Power Status," Chinese Journal of International Politics, Vol. 1, No. 1 (2006), p. 26. The CASS index only looks at individual states and does not include an aggregate measure for the European Union.

${ }^{12}$ Jing-dong Yuan, Asia-Pacific Security: China's Conditional Multilateralism and Great Power Entente (Carlisle, PA: Strategic Studies Institute, US Army War College, 2000), pp. 4-17.

${ }^{13}$ Bessma Momani, "China at the International Monetary Fund: Continued Engagement in Its Drive for Membership and Added Voice at the IMF Executive Board," Journal of Chinese Economics, Vol. 1, No. 1 (2013), pp. 125-150.

${ }^{14}$ For a China-focused take on this core International Relations assumption, please see Alistair Iain Johnston, "Is China a Status Quo Power?" International Security, Vol. 27, No. 4 (2003), pp. 5-56. 
expect China to act like other modern major powers. Shi contends that the Chinese way of thinking is less universalist and more particularist than Western thought and this, combined with China's more conservative political culture, makes China more wary of universal causes and their attendant international commitments. ${ }^{15}$ Shi's argument reflects a very longstanding debate about different philosophical approaches by "Eastern" and "Western" states and how these different approaches and positions of these states in the inter-state system affect their views of international relations and even the nature of international relations themselves. ${ }^{16}$

In summation, this view of China is that China is too poor, inexperienced, weak, and culturally distinct to live up to the status as one of the only two major global powers and the expectations of international leadership as well as the responsibility this status entails. For its proponents, the greatest contribution China can make to the world, and the one it should be primarily judged on, is to continue with domestic economic reforms and sustainable economic development. In 1978, Deng Xiaoping packaged this approach under the phrase "realize four modernizations and never seek hegemony."17

\section{Status Convergence}

It appears that China is moving beyond Deng's doctrine. The first two years of Chinese foreign policy under $\mathrm{Xi}$ Jinping strongly suggest a convergence of these differing external and internal views of China's power status in favor of recognizing China as one of the two major global powers. This is inevitable as China's continuing high levels of economic growth and military spending are rapidly eroding the credibility of Chinese appeals to comparative poverty and weakness. The World Bank already classifies

${ }^{15}$ Cited in Maarten van den Berg, “China's Foreign Policy Dilemmas," The Broker, June 2, 2011.

${ }^{16}$ For a China-focused articles on this theme, please see Qin Yaqing, "Why Is There No Chinese International Relations Theory?" International Relations of the Asia-Pacific, Vol. 7, No. 3 (2007), pp. 313-340 and Feng Zhang, "The Rise of Chinese Exceptionalism in International Relations," European Journal of International Relations, Vol. 19, No. 2 (October 2011), pp. 305-328.

${ }^{17}$ Angang $\mathrm{Hu}$, "China and the World: Assessment and Prospect of the 'Post-Crisis' Era," in Fu Xiaolan, ed., China's Role in Global Economic Recovery (New York: Routledge, 2012), p. 97. 
China as an "upper middle income" member along with Malaysia and Thailand, and above China's "low middle income" neighbors such as Indonesia, the Philippines, and Vietnam.

Public opinion around the world is even more bullish on China. A growing number of countries polled already identify China as the leading economy in the world. In a 2014 Pew survey, Americans were evenly split on whether the United States or China can lay claim to this title, while a plurality in the United Kingdom, Germany and Russia and a majority in France opted for China. ${ }^{18}$ In 2013, 61 percent of Australians polled by the Lowy Institute believed that China will eventually overtake the United States as the world's leading superpower; 12 percent believed that China already has done so. ${ }^{19}$

More importantly, Chinese foreign policy under Xi Jinping appears to have moved beyond Deng's cautious and cautionary approach and is much more in line with what one would expect from a reemerging power that accepts its status as a major global power on the rise. Chinese foreign policy signs of major power status acceptance certainly occurred before Xi Jinping became president in late 2012. Foreign Minister Yang Jiechi's reaction at the 2010 ASEAN Regional Forum meeting where he felt Southeast Asian states were ganging up with the United States against China over the South China Sea disputes clearly differentiated China from its Southeast Asian neighbors in clear power terms. Yang is cited as clarifying that "China is a big country and other countries are small countries and that's just a fact." ${ }^{20} \mathrm{Xi}$ Jinping in a well-received address to the joint sitting of the Australian parliament in November 2014 offered a more conciliatory take on China's huge and growing size and power differential over other states in the region and the reactions this differential foments,

Many people applaud China's achievements and have great confidence in China, while some others have concerns about

${ }^{18}$ Richard Wike et al., "Balance of Power: U.S. vs. China," in Global Opposition to U.S. Surveillance and Drones, but Limited Harm to America's Image (Washington DC: Pew Research Center, July 14, 2014), p. 36.

${ }^{19}$ Alex Oliver, The Lowy Institute Poll 2013: Public Opinion and Foreign Policy (Sydney, Lowy Institute for International Policy, 2013), p. 19.

${ }^{20}$ Cited in Ian Storey, "China's Missteps in Southeast Asia: Less Charm, More Offensive," China Brief, Vol. 10, No. 25 (December 17, 2010), p. 4. 
China - and there are also people who find fault with everything China does. I think these diverse views are to be expected. After all, China is a large country of over 1.3 billion people. It is like the big guy in the crowd. Others naturally wonder how the big guy will move and act, and they may be concerned that the big guy may push them around, stand in their way or even take up their place. $^{21}$

As implied in the citation above, it appears that China's acceptance of its status as one of the only two major powers and its attendant responsibilities (and the responsibilities of other states to China) is clear and being translated into Chinese foreign policy actions and intentions. At the U.S.-China Sunnylands Summit at the very beginning of President Xi's first term, he announced the idea of a "new type of great power relations" that would avoid the historic trap of conflict between a rising or reemerging major power and the declining incumbent, one that the world witnessed in both major world wars. Reflecting the depth of China-Russia relations, Xi's formulation and its application to U.S.-China relations closely resembles the "new type of relations" framework for the repairing China-Russia relationship in the early 1990s. ${ }^{22}$

APEC 2014 in Beijing was among the first major international meeting hosted by $\mathrm{Xi}$ Jinping and reinforced the image of a China

It appears that

China's acceptance of its status as one of the only two major powers and its attendant responsibilities (and the responsibilities of other states to China) is clear and being translated into Chinese foreign policy actions and intentions.

${ }^{21}$ Chinese President Xi Jinping's address to Australia's Parliament, Straits Times Online, November 19, 2014 http://www.straitstimes.com/news/asia/australianew-zealand/story/fulltext-chinese-president-xi-jinpings-address-australias-parl\#sthash.nBW4bny1.dpuf

${ }^{22}$ Paul Mancinelli, “Conceptualizing 'New Type Great Power Relations': The SinoRussian Model," China Brief, Vol. 14, No. 9 (May 7, 2014), pp. 12-16. 
comfortable in its status as one of the two major powers globally. President $\mathrm{Xi}$ returned the unprecedented protocol honor of Obama's Sunnylands Summit and hosted two days of personal and less diplomatically restrictive talks with President Obama. The new type of great power relations framework was given a boost by the bilateral climate change deal agreed to by both leaders. In sharp contrast to Copenhagen in 2009, the international coverage of the bilateral climate change deal, despite its generality and uncertain feasibility, was positive and framed as the U.S. and China taking the lead in addressing this global problem ${ }^{23}$; a very good reversal of fortunes for China on the global stage. China's second hosting of an APEC summit was also much grander than the first in 2001 or any previous APEC summit. The People's Daily opined that it reflected that the "center of world power is shifting toward the East," and that the welcome dinner was reminiscent of China's relations with other states during China's first period as a global great power. ${ }^{24}$

The second element of Chinese foreign policy under Xi Jinping that is very much in line with the expectations of a great power has been termed "China's new multilateralism." Building on the regionally focused Shanghai Cooperation Organization (SCO) established in 2001 under Jiang Zemin, $\mathrm{Xi}$ has announced a long and growing list of new China-centered global and regional multilateral bodies and unilateral policies with a regional and global reach. The globally oriented New Development Bank announced at the BRICS summit in 2013 to be based in Shanghai will be joined in 2015 by the Asian Infrastructure Investment Bank (AIIB) to be headquartered in Beijing. Both will provide alternate sources of funding to the America-centered World Bank and the Japan-centered Asian Development Bank. China is also the largest initial contributor to both accounting for 41 percent of the New Development Bank's initial \$100 billion capitalization and at least half of the Asian Infrastructure Investment Bank's $\$ 50$ billion one. At APEC 2014, China announced up to $\$ 40$ billion in support for its "New Silk Road" initiative to develop new land and maritime infrastructure to link all parts of the Eurasian landmass and

${ }^{23}$ Simon Hansen, "The China-US Climate Change Agreement is a Step Forward for Green Power Relations," The Guardian, November 14, 2014.

${ }^{24}$ Cited in Wang Xiangwei, "Towards a New Order, Xi Jinping Touts Asia-Pacific Dream," South China Morning Post, November 17, 2014. 
Indo-Pacific maritime region. Less concretely, China used its 2014 hosting of the Conference on Interaction and Confidence-Building Measures in Asia (CICA), the largest regional meeting hosted by Xi Jinping, to publicly consider a new inclusive Asian security order to solve Asian security problems. ${ }^{25}$

Any one of these regional and international public good announcements with attached yuan would be an impressive signal of China's acceptance of its new status. Together, they account for the strongest institution-building commitment by any major global power since the United States in the immediate postwar era. In short, Chinese foreign policy under $\mathrm{X} i$ Jinping has embraced China's status as one of the two global major powers and Asia's leading one.

\section{East Asian Challenges}

China's embrace of its new power status and the attendant responsibility to provide public goods and the right to reshape the existing order in favor of its interests will have the greatest impact on East Asia. Through APEC and the growing number of ASEAN-based East Asian regional bodies, China is deeply enmeshed in East Asia's regional architecture, one largely constructed by others. How China's new multilateralism and its Asian regional focus interacts with these existing bodies and the organizing principle of "ASEAN centrality" will be a key determinant of this existing architecture's future evolution and continued relevance. Befitting a continental rather than a maritime power, China has long had and continues to hold a different conceptualization of Asia than the maritime one which underpins APEC and the ASEAN-based bodies. ${ }^{26}$ The Shanghai Cooperation Organization, the Asian Infrastructure Investment Bank, and the Conference on Interaction and Confidence-Building Measures in Asia have membership that encompasses states from East Asia, South Asia, Central Asia, and West Asia.

${ }^{25}$ Shannon Tiezzi, "At CICA, Xi Calls for New Regional Security Architecture," The Diplomat, May 22, 2014.

${ }^{26}$ Anthony Bubalo and Malcolm Cook, "Horizontal Asia," The American Interest, Vol. 5, No. 5 (Summer 2010), pp. 12-18. 
While China's new multilateral aspect of its acceptance of its major power status may challenge East Asia, China's actions in East Asia and East

China's actions in

East Asia and East

Asian states'

responses to them

will be central to the

global acceptance of

China as a major

power.
Asian states' responses to them will be central to the global acceptance of China as a major power. One early sign of greater global interest in and reaction to China's actions in East Asia was the June 4, 2014, G7 Leaders' Communique. ${ }^{27}$ This Atlanticist organization of major powers with only one Asian member stated:

territorial or maritime claims through the use of intimidation, coercion or force. We call on all parties to clarify and pursue their territorial and maritime claims in accordance with international law. We support the rights of claimants to seek peaceful resolution of disputes in accordance with international law, including through legal dispute settlement mechanisms."

This unprecedented statement went further than even the May 10, 2014, "ASEAN Foreign Ministers Statement on the Current Developments in the South China Sea." ${ }^{28}$ The G7 statement of deep concern includes the territorial disputes in both the East and South China Seas and public support for the use of legal dispute settlement mechanisms. China has chosen not to participate in the Philippines' request for the International Tribunal on the Law of the Sea to adjudicate on the bilateral maritime boundary dispute between the Philippines and China on the basis that the tribunal does not have jurisdiction, a question the tribunal itself is considering.

${ }^{27}$ G7 Leaders' Communique, June 4, 2014, http://europa.eu/rapid/press-release_IP-14637_en.htm

${ }^{28}$ ASEAN Foreign Ministers' Statement on the Current Developments in the South China Sea, May 9, 2014, http://www.asean.org/news/asean-statement-communiques/item/ asean-foreign-ministers-statement-on-the-current-developments-in-the-south-china-sea 
Chinese observers also have queried the motives behind the G7's expression of deep concern over tensions in the East and South China Seas particularly when the only Asian member of this body is an active disputant. $^{29}$

\section{Hegemonic Fears}

As referred to in Deng's doctrine, Beijing has consistently represented Chinese foreign policy as anti-hegemonic, in favor of greater "democracy" in international relations, and supportive of a multipolar global order with China as one pole. This stated commitment to multipolarity and antihegemonism has been key to China's growing engagement with other similarly minded rising or reemerging powers, particularly Russia and India. The Shanghai Cooperation Organization, the trilateral China-RussiaIndia meetings, and the wider BRICS (Brazil, Russia, India, China, and South Africa) ones all make reference to these principles.

In a speech on May 15, 2014 at the China International Friendship Conference in Commemoration of the 60th Anniversary of the Chinese People's Association for Friendship with Foreign Countries, President Xi went as far as to note that "the Chinese people do not have the gene for invasion and hegemony in their blood." ${ }^{30}$ Rather, China often perceives American actions in East Asia as hegemonic in tone and purpose. At the 2014 Shangri-La Dialogue, Lieutenant General Wang Guanzhong, commenting on U.S. Secretary of Defense Hagel's earlier speech, complained that, "Mr. Hagel was more outspoken than I expected. And I personally believe that his speech is a speech with a taste of hegemony, a speech with expressions of coercion and intimidation." ${ }^{31}$

Yet in East Asia (both Northeast and Southeast Asia), fears of future Chinese hegemony and unilateral assertiveness increasingly shape how

${ }^{29}$ Teddy Ng, "Beijing Tells G7 Nations to Stay Out of Disputes," South China Morning Post, June 6, 2014.

${ }^{30}$ President Xi's speech China International Friendship Conference in Commemoration of the 60th Anniversary of the CPAFFC, May 15, 2014, http://en.cpaffc.org.cn/content/ details25-47426.html

${ }^{31}$ Wang Guanzhong, "Major Power Perspectives on Peace and Security in the AsiaPacific," Shangri-La Dialogue 2014, June 4, 2014, http://www.iiss.org/en/events/shangri\% 20la\%20dialogue/archive/2014-c20c/plenary-4-a239/wang-guanzhong-2e5e 
regional observers and states perceive China's reemergence. China's globally oriented narrative of anti-hegemonism, anti-intimidation, and multipolarity finds little resonance in many East Asian views of China's actions in East Asia. Rather East Asian officials, commentators, and the public frequently fear that the "big guy (President Xi referred to in Canberra) may push them around, stand in their way or even take up their place."

China's remergence and Southeast Asian concerns about future Chinese influence in the region is one of the factors behind the greater commitment to "ASEAN centrality" among Southeast Asian states. The ASEAN decision to expand membership of the East Asia Summit beyond the originally planned thirteen states (the 10 ASEAN states, China, Japan and South Korea) of the ASEAN +3 process to first include India, Australia and New Zealand then later the United States and Russia is seen by many analysts as stemming from the concerns of some ASEAN member states that China held too much sway in the ASEAN +3 process. ${ }^{32}$ In the same vein, Southeast Asian states moved from supporting China's active promotion of an East Asia Free Trade Agreement, again limited to the ASEAN +3 countries, to preferring the ASEAN-based Regional Comprehensive Economic Partnership process that is broader in membership than the ASEAN+3 process and open to future expansion beyond the 16 states presently involved. ${ }^{33}$ Southeast Asian states have welcomed President Xi's championing of the even broader Free Trade Area of the Asia-Pacific (FTAAP), an idea that has been developing in APEC circles for the last decade.

According to Vitaly Kozyrev, Russia under President Putin at the peak of his conflict with Western powers is making similar East Asian regional architecture choices for similar reasons:

It is clear from the proceedings of the regional summits that, despite the tilt toward China, the fundamentals of Moscow's pivot to Asia under the new circumstances have not changed. While sharing with China a common stance toward regional

${ }^{32}$ Mohan Malik, "The East Asia Summit: More Discord than Accord," YaleGlobal, December 20, 2005.

${ }^{33}$ Tan See Seng, “East Asia Summit 2010: Big Step Forward or Business-as-Usual," RSIS Commentaries, No. 141 (November 4, 2010), p. 2. 
security architecture, Moscow in practice supports a broader framework which equally embraces all interested Pacific actors. ${ }^{34}$

Unsurprisingly, disputants from Japan to the Philippines to Vietnam are the most frequent and public in their expressions of fears of China, while downplaying their own destabilizing actions. Prime Minister Abe of Japan and President Aquino compared China to WWI Germany and WWII Germany respectively. ${ }^{35}$ This sense of anger and fear toward China is not limited to political leaders but is widespread in the affected countries' populations. In the case of Japan and Vietnam, the fact that China is the reemerged leading power in East Asia may deepen collective fears of China today given the fraught histories between China and Vietnam, and China and Japan during the previous period of Chinese regional leadership. ${ }^{36}$

East Asian concerns over widely perceived Chinese unilateral actions go beyond China's relations with the states in active dispute with China in the South and East China Seas. South Korea, Australia, and the United States each criticized China's November 2013 announcement of an Air Defense Identification Zone in the East China Sea. ASEAN, as the regional

Table 1. Favorable Views.

\begin{tabular}{cccc}
\hline Respondent Country & China & U.S. & Japan \\
\hline Japan & $7 \%$ & $66 \%$ & - \\
Philippines & $38 \%$ & $92 \%$ & $80 \%$ \\
Vietnam & $16 \%$ & $76 \%$ & $77 \%$ \\
India & $31 \%$ & $55 \%$ & $43 \%$ \\
Indonesia & $66 \%$ & $59 \%$ & $77 \%$ \\
South Korea & $56 \%$ & $82 \%$ & $22 \%$ \\
China & - & $30 \%$ & $8 \%$ \\
\hline
\end{tabular}

Source: Pew Research Center, Spring 2014 Global Attitudes Survey.

${ }^{34}$ Vitaly Kosyrev, "Russia Plays a Pragmatic Game on the Chinese Chessboard at APEC and the EAS," Asia Pacific Bulletin, No. 291 (November 21, 2014), p. 2.

${ }^{35}$ Cited in Zachary Keck, "Asia Plays the Nazi Blame Game," The Diplomat, February 5, 2014.

${ }^{36}$ Huong Le Thu, "Vietnam: Straddling Southeast Asia's Divide," Trends in Southeast Asia 2014/5 (Singapore: ISEAS, 2014), pp. 12-16. 
body of the ten Southeast Asian states, has played an active role in managing the diplomatic fallout from China's territorial and maritime boundary disputes with the Philippines, Vietnam, Malaysia, Brunei Darussalam, and Indonesia in the South China Sea. Ironically, ASEAN has played a more active role in disputes involving China in these waters than those among ASEAN member states themselves. The lead opinion piece on November 27, 2014, in the Straits Times of Singapore, a non-disputant in the South China Sea, summed up the present prevalent feeling in Southeast Asia:

\begin{abstract}
Mr Xi spoke about an 'Asia-Pacific dream' of shared prosperity at this month's APEC summit. At the same meetings, China established the Asian Infrastructure Investment Bank, started the Silk Road fund and pushed for a Free Trade Area of the Asia-Pacific. It doesn't take too much to see that such worthy aspirations will always be at odds with gunboat diplomacy. China's leaders ought to acknowledge the counter-productivity of such a dual approach and lend credence to $\mathrm{Mr} \mathrm{Xi}^{\prime}$ s pledge by giving precedence to consultation. A good start would be to play an active role to conclude a binding Code of Conduct in the South China Sea. ${ }^{37}$
\end{abstract}

Recent moves by China to start negotiations on a Code of Conduct, as called for in the 2002 ASEAN-China Declaration on the Conduct of Parties in the South China Sea have been welcomed in Southeast Asia and ASEAN, while its continued dredging and reclamation activities in the disputed waters and land features of the South China Sea and assertions that such actions are fully in China's sovereign rights much less so.

\title{
Illiberal Separation?
}

A core assumption of Liberal International Political Economy that is widely held outside of academia as well is that closer trading relations between economies help align the diplomatic and political relations between the respective states. ${ }^{38}$ The more you trade together, the less likely you are to

37 “Holding China to Its Pledge of Peace,” The Straits Times, November 27, 2014.

${ }^{38}$ For a China-focused testing of this hypothesis, please see James R. Masterson, "Analysing China's Economic Interdependence and Political Relations with Its Neighbours," China Information, Vol. 26, No. 1 (March 2012), pp. 3-33. 
go to war. Chinese officials repeatedly and correctly refer to the great benefit other economies have derived from China's rapid, sustained and continued economic growth and opening-up and the frustration that this has not been effectively translated into greater political acceptance of China and its leading role in East Asia and globally. China is now the largest trading partner of over 100 countries in the world but as Yan Xuetong notes in discussion of the foreign policy challenges facing President Xi:

We have few friends. We are the world's second largest economy, but we have fewer friends than the United States does. Washington may have about 40 allies, but we have (virtually) zero. $^{39}$

Relations with Japan, China's second largest trading partner (after the United States) and largest source of imports, best reflect this risk of illiberal separation. For the last three decades, China-Japan trade has expanded rapidly as has the importance of this trade for both economies. Yet at the same time, over the ten years that the Japanese non-profit organization Genron and China Daily have polled Chinese and Japanese feelings toward each other, Japanese views of China have steadily worsened. In 2005, only 37.9 percent of Japanese had an unfavorable view of China. By 2014, 93 percent were so inclined. Polling by Japan's Cabinet Office shows a very similar trajectory in Japanese public opinion toward China from the 1980s onward. ${ }^{40}$ Tokyo's increasingly hardline position on Japan-China diplomatic and defense relations has both bipartisan support and clearly echoes Japanese public opinion. Chinese views of Japan have been growing more negative as well. In 2005, 62.9 percent of Chinese polled had an unfavorable view of Japan, bottoming out in 2007 at 36.5 percent before steadily rising to 86.8 percent in $2014 .^{41}$

${ }^{39}$ Koichi Furuya, “Interview with Yan Xuetong: 'Conflict Control' is Key to U.S.-China Relations in a Bipolar World," Asahi Shimbun, May 14, 2014.

${ }^{40}$ Matthew Linley, "Unfriending: Japanese Public Opinion on China," Lowy Interpreter, January 22, 2013.

${ }^{41}$ The Tenth Japan-China Public Opinion Poll (Tokyo: Genron NPO and China Daily, 2014), p. 3. 
More controversially, regional perceptions of Chinese actions act

Regional perceptions of Chinese actions act against the realization of this liberal synergy between trade and politics in East Asia and more broadly. against the realization of this liberal synergy between trade and politics in East Asia and more broadly. The virtuous circle assumed in liberal thought between closer economic relations and better strategic ones is premised on the involved states not using (or being perceived to use) economic threats and sanctions to achieve strategic outcomes. If economic policy actions are seen to be determined by competitive strategic tensions, then this virtuous circle can become a vicious one.

In East Asia, a set of story lines based on this negative reading of Chinese perceived or real actions have proliferated recently. The perception that China restricted crucial rare earth exports to Japan in reaction to the September 2010 clash between a Chinese fishing vessel and a Japanese Coast Guard in disputed waters in the East China Sea gained blanket international coverage. Later research from the Australian National University questioning the veracity of this perception received minimal coverage. ${ }^{42}$ The news cycle had moved on. Likewise, China's comparatively very small contribution to disaster relief after super-typhoon Haiyan hit the central Philippines was widely perceived as a Chinese non-action in retaliation against the Philippines taking its maritime boundary dispute with China to the International Tribunal for the Law of the Sea. The fact that Coke and IKEA's initial pledges were larger than China's second, improved one and the assumption that China was doing so to "punish" the Philippines became an international headline. ${ }^{43}$ The tense nature of strategic relations between China and the Philippines in late 2013 encouraged this critical perception of events.

While many states large and small repeatedly use economic threats and sanctions to address strategic concerns, the negative reputational

${ }^{42}$ Amy King and Shiro Armstrong, "Did China Really Ban Rare Exports to Japan?" East Asia Forum, August 18, 2013.

${ }^{43}$ There were a plethora of international media stories using this headline and tagline. One example is Christopher Bodeen, "China Beat by Ikea, Coke in Giving Relief to TyphoonHit PHL," Associated Press, November 15, 2015. 
effects of Chinese threats and sanctions, perceived or real, are greater for China for two reasons. First, China's imposition of sanctions is seen to be categorically different than the approach of most Western states. As James Reilly notes:

Unlike U.S. sanctions, which are formalized through domestic law and/or presidential decisions, China rarely openly declares its economic sanctions. Instead, Beijing prefers to use vague threats, variations in leadership visits, and other informal or indirect measures, enhancing Beijing's flexibility while minimizing diplomatic fallout. ${ }^{44}$

On the other hand, the perception that China follows this opaque approach does leave China open to criticism that it is applying such covert sanctions when it may not be, while also undermining the immediate credibility of Chinese denials. Second, the perception, with seemingly convincing empirical evidence in some cases, of Chinese economic sanctions against states it has political disagreements with, runs counter to China's long-standing and vocal opposition against the use of formal sanctions. The prevalence of media stories on such Chinese sanctions also undercuts China's efforts to counter the "China threat" thesis among East Asian countries and beyond and Chinese efforts to represent itself as a "responsible member of the international economic system. ${ }^{\prime 45}$

\section{Welcome Presence}

The biggest gap between China's vision for East Asia and the responses of East Asian states to the reemergence of China as the region's leading power may well be over the role of the United States in East Asia's security order. China is calling for a new Asian security order for Asians to solve Asian problems. ${ }^{46}$ China repeatedly rebuffs U.S. arguments that it has vital

44James Reilly, “China's Economic Statecraft: Turning Wealth into Power," Lowy Institute Analysis (Sydney: Lowy Institute for International Policy, November 2013), p. 8.

45James Reilly, "China's Unilateral Sanctions," The Washington Quarterly, Vol. 35, No. 4 (Fall 2012), p. 130.

${ }^{46}$ Kor Kian Beng, “Don't Bet on China's 'Asia for Asians Only' Vision Yet," The Straits Times, May 30, 2014. 
interests at stake in the East and South China Seas and tells Washington to butt out. This is consistent with China's long-standing, negative view of the United States' alliance system in East Asia, an alliance system that many other East Asia states see as contributing significantly to East Asia's long period of relative strategic peace and stability. Wu Xinbo of Fudan University argues that:

Given its history from World War II through the collapse of the Soviet Union, the United States' perspective is saturated with realist thinking about things such as power balance, geopolitics, military alliances, and zero-sum games. Washington manifests a proclivity for overemphasizing national security concerns, seeking superior military might, and securing hegemony. It is this thinking and ensuing practices that have given rise to Beijing's distrust of Washington. ${ }^{47}$

Yet, it seems that East Asian states' concerns about China's position in the regional security order now and in the future are reinforcing the longstanding view in many regional capitals that a United States actively and constructively engaged in Asia is required for regional stability. Since the announcement of the pivot policy in President Obama's first term, the debate in East Asia, outside of China, has been more about whether the pivot has actually occurred and what more the U.S. should do to prove and sustain the pivot. ${ }^{48}$

In the last five years, with strong bipartisan support, Australia and Japan have deepened their alliance relationships with the United States and agreed to "share more of the burden." Trilateral strategic cooperation between Australia, Japan, and the United States has become more institutionalized, active across a much wider spectrum, and more willing to collectively express concerns about regional security matters involving China. The October 4, 2013, joint statement from the Trilateral Strategic

${ }^{47} \mathrm{Wu}$ Xinbo, "Agenda for a New Great Power Relationship," The Washington Quarterly, Vol. 37, No. 1 (Spring 2014), p. 68.

${ }^{48}$ Rajeswari Pillai Rajagopalan, "Reassessing the US Pivot to Asia," Analysis (New Delhi: Observer Research Foundation, August 26, 2013). 
Dialogue noted:

Ministers opposed any coercive or unilateral actions that could change the status quo in the East China Sea. They underlined the importance of efforts to reduce tensions and to avoid miscalculations or accidents in the East China Sea, including by improving maritime communications.

The ministers affirmed the importance of peace and stability, respect for international law, unimpeded trade and freedom of navigation in the South China Sea. They called on claimants to refrain from actions that could increase tensions, to clarify and pursue claims in accordance with international law, including the 1982 United Nations Convention on the Law of the Sea (UNCLOS), and for ASEAN and China to agree on a meaningful Code of Conduct. ${ }^{49}$

With strong public backing, President Aquino signed the Enhanced Defense Cooperation Agreement twelve years after the Philippine Senate rejected renewing the lease on the U.S. bases at Clark Air Field and Subic Bay.

Present alliance dynamics in South Korea and Thailand are less robust and less driven by shared concerns over China's growing strategic and military presence and activities in East Asia. Facing nuclear-tipped uncertainty and belligerence from North Korea, Seoul has requested the indefinite postponement of the transfer of wartime control of South Korean troops from U.S. command. Yet, at the same time, South Korea has demurred from joining the U.S.-led regional ballistic missile defense system, preferring to focus its capabilities on intercepting short-range missiles. Analysts argue that China's concerns with the U.S.-led system that focused on longer-range missiles lie behind South Korea's decision to go against the wishes of Washington. ${ }^{50}$

Thailand's concerns over its alliance relationship with the United States negatively affecting relations with China seem even greater. In June 2012,

\footnotetext{
${ }^{49}$ The joint statement can be downloaded at http://www.japanportal.jp/ MOFA000016195.pdf

50 "South Korean Military Weighing Purchase of More Aegis Antimissile Destroyers", Global Security Newswire, October 16, 2013.
} 
the Thai government delayed its approval of the request by NASA for the use of a Thai military airbase for atmospheric studies of Southeast Asia due to Thai suspicions of NASA's real intent. ${ }^{51}$ Thailand's recent repeated lurches to military rule and the U.S. condemnation of these have furthered deepened Thai concerns about its alliance relationship with the United States.

Not only have the majority of U.S. alliances in the region deepened recently, but the depth and number of active U.S. strategic partnerships has increased as well. Long-standing ones as with Singapore, the only non-ally to host a PACOM command and to home-port U.S. combat ships, have deepened. New ones like Vietnam and India have developed rapidly despite the adversarial Cold War history between the United States and India and the war-ravaged one between Vietnam and the United States. East

East Asian states, in relation to the United States, are moving beyond Cold War thinking but not in the way China is encouraging them. Asian states, in relation to the United States, are moving beyond Cold War thinking but not in the way China is encouraging them. As noted by a reviewer, the risk is that some may be moving toward a new form of Cold War thinking against China.

A similar pattern of greater engagement with the United States and rejection of its exclusion from or reduced presence in East Asia is replicated in East Asian views on regional architecture. Led by Indonesia, Singapore, and the Philippines, Southeast Asian states have included the United States in the East Asia Summit, the ASEAN Defense Ministers-plus process and the Expanded ASEAN Maritime Forum that are all ASEAN-based. Singapore Prime Minister Lee Hsien Loong also reminded Prime Minister Hatoyama of the sagacity of including the United States in East Asian affairs when it appeared that Hatoyama's East Asian Community concept excluded the United States. ${ }^{52}$

51 Sasiwan Chingchit, "After Obama's Visit: The US-Thailand Alliance and China", Asia Pacific Bulletin, No. 189 (Washington DC: East-West Center, December 4, 2012), p. 1.

${ }^{52}$ Cited in Akio Takahata, "A Shaky Start for Hatoyama's Yuai Diplomacy," Tokyo Foundation, November 13, 2009. 


\section{Two Responses}

This article has focused on three nascent East Asian challenges for China in its embrace of its reemergence as one of the two major global powers and East Asia's leading one that could become broader and deeper in the future and pose more problems for China's evolving major power foreign and strategic policy. Clearly this is far from the complete story of China's current and future relations with East Asian states. The fact that all the ten Southeast Asian states and Mongolia signed up as prospective founding members of the Asian Infrastructure Investment Bank is a positive sign of regional acceptance of China's leading position. Yet in the interests of revising policy and the communication of policy to those affected by it to enhance trust and cooperation and reduce mistrust and opposition, Chinese policymakers should consider two responses to the increasingly clear signs of East Asian concern with China as one of two major global powers and East Asia's leading one. Both call for China to further embrace its new status and the attendant responsibilities to other states. Both are consistent with Chinese foreign policy pronouncements.

\section{More Talk, Less Action}

China's recent much reported actions in the South and East China Seas are at the core of much of the regional distrust with each new incident reaffirming this distrust among other claimants, neighboring countries, and states that have valid, crucial interests in the stability of the vital sea lines of communication and commerce that criss-cross these waters. The more powerful China becomes, the more capable it is to exercise what it claims are its sovereign rights and the more other states will be concerned and react accordingly to Chinese actions. This same burden of greater power manifests itself in the greater regional concern with Chinese actions in these disputed waters deemed more destabilizing than the recent or past actions of other claimants. While Japan exercises more control over the disputed islands in the East China Sea, Vietnam controls the most number of islands in the South China Sea and Taiwan the largest one, Chinese actions gain the most critical coverage due to China's much greater power and regional states' fears about China's strategic intentions more generally.

As China has requested of Japan that administers the disputed islands in the East China Sea, China should recognize that its claims in the South 
China Sea are not indisputable but rather very much in dispute by neighboring, smaller countries. ${ }^{53}$ In accordance with the 2002 ASEAN-China Declaration on the Conduct of Parties in the South China Sea, China would reduce distrust and minimize criticisms if it abided by Article 5 that states,

\begin{abstract}
The Parties undertake to exercise self-restraint in the conduct of activities that would complicate or escalate disputes and affect peace and stability including, among others, refraining from action of inhabiting on the presently uninhabited islands, reefs, shoals, cays, and other features and to handle their differences in a constructive manner. ${ }^{54}$
\end{abstract}

China publicly indicating when other claimants are not acting in line with this Article is fully justified as are Chinese references to past and present Vietnamese and Philippine actions in contravention of Article 5. Such criticisms by the biggest state of the actions of the smaller would be more effective if Chinese actions were and were seen to be faithful to the signed declaration.

China has long held that peaceful cooperative bilateral discussions between claimants, rather than multilateral approaches and the use of international legal mechanisms, is the only means to address the sovereign claims at the heart of these disputes. A public announcement by China of the commencement or recommencement of such talks with other claimants would again cast China's actions, perceived and real, in the South and East China Seas in a different and more positive light. It would also counter repeated criticisms that China is not engaging in constructive bilateral talks. ${ }^{55}$ The brief first-time meetings between President $X_{i}$ and Prime Minister Abe and President Xi and President Aquino at APEC 2014 offer a promising beginning to build on. The recent successful conclusion of bilateral maritime boundary dispute talks between the Philippines and

${ }^{53}$ Matikas Santos, “China Claims 'Indisputable Sovereignty' over Reclamation on Mabini Reef," Philippine Daily Inquirer, May 16, 2014.

${ }^{54}$ Declaration on the Conduct of Parties in the South China Sea, November 4, 2002 http://www.asean.org/asean/external-relations/china/item/declaration-on-the-conduct-ofparties-in-the-south-china-sea

${ }^{55}$ Pia Lee-Brago, "Bilateral Talks with China on Sea Row Impossible-DFA," Philippine Daily Inquirer, July 16, 2013. 
Indonesia is another sign of the promise offered by more bilateral talks and less unilateral actions.

\section{More Inclusion, Less Control}

The perception, reaffirmed by the public comments of some Chinese scholars and officials at regional meetings, that China wants to push the United States out of the region despite the U.S. long presence and deep ties with most East Asian states is at the core of much of East Asian disquiet over China's intentions as East Asia's leading power. The first U.S.-ChinaAustralia trilateral military exercise near Darwin in October 2014 and China's first participation in the U.S.-led multilateral RIMPAC naval exercises off Hawaii are both positive signs for U.S.-China strategic relations and the strategic judgments East Asian states make premised on their reading of U.S.-China relations. Likewise with the recent U.S.-China agreements on prior notice of major military actions and on unexpected encounters in the air and at sea. Expanding the scope of such major power cooperation between the U.S. and China and the inclusion of other East Asian states in such signals of cooperation would be a powerful confidencebuilding measure positively affecting regional views of U.S.-China relations and of China itself. This would definitely be a sign of "casting away the Cold War mentality and the antiquated way of thinking."

China's new multilateralism could benefit from lessons from America's successful postwar "liberal hegemony." ${ }^{57}$ Providing weaker and smaller states a greater say in multilateral bodies reduces fears that these bodies are purely tools of the most powerful states and encourages greater support for these bodies by the smaller member states. ASEAN works well because Indonesia recognizes this. The fact that the Asian Development Bank is located in Manila and

China's new multilateralism could benefit from lessons from America's successful postwar "liberal hegemony."

${ }^{56} \mathrm{Yu}$ Hongjun, "China and the United States: Building New Relations between Major Powers," China International Studies, No. 42 (September/October 2013), p. 18.

${ }^{57}$ Daniel Deudney and G. John Ikenberry, "The Nature and Sources of Liberal International Order," Review of International Studies, Vol. 25, No. 2 (April 1999), pp. 179-196. 
not Tokyo or Osaka and that Japan and the United States have equal capital contributions eased fears of the bank as a tool of Japanese economic hegemony, fears that were very prevalent in East Asia in the mid-1960s. ${ }^{58}$

The location of the Asian Investment Infrastructure Bank in Beijing and China's dominant share of its initial capital have sparked concerns among states that were approached as prospective founding members and chose to wait and see. ${ }^{59}$ The rebuffing of South Korea's offer to host the bank is also consistent with this concern. Even leading figures in co-founding states have expressed doubts about the inclusive nature of the bank. ${ }^{60}$ Repositioning the Asian Infrastructure Investment Bank as an "Asian" and not simply a "Chinese" bank will be key to its success and regional acceptance of China's new multilateralism as would close and visible cooperation between the Asian Infrastructure Investment Bank and the Asian Development Bank. Very close links between China's Silk Road initiatives and the Asian Infrastructure Investment Bank would likely achieve the opposite.

Chinese foreign policy under Xi Jinping has embraced China's status change and its attendant responsibilities and rights. China's huge size, historic reemergence, and rapid and continuing economic growth make it a unique major global power and leading East Asian one. This uniqueness means East Asian states and states around the world will be watching China's actions in East Asia very carefully and with some forbearance. Matching Chinese actions and the perceptions of these actions by others with China's rhetoric of peaceful development, democratic regional and international relations, and anti-hegemonism will be key. Strategic trust is required for true confidence building and acceptance. The larger and the more powerful a state is, the harder it is to develop and maintain strategic trust. The larger and more powerful a state is, the more likely other states are to fear that it "may push them around, stand in their way or even take up their place" and the harder it is to counteract this perception.

${ }^{58}$ Ming Wan, “Japan and The Asian Development Bank," Pacific Affairs, Vol. 68, No. 4 (Winter 1995-1996), pp. 509-528.

${ }^{59}$ Philip Coorey, “Australia Offered Top Role in China's \$57 Billion Infrastructure Bank," Australian Financial Review, November 3, 2014.

${ }^{60}$ Kasit Piromya, "Asian Nations Wary of China's New Infrastructure Bank," Nikkei Asian Review, November 27, 2014. 